\title{
Analyzing the major drivers of NEE in a Mediterranean alpine shrubland
}

\author{
B. R. Reverter ${ }^{1,2}$, E. P. Sánchez-Cañete ${ }^{3}$, V. Resco ${ }^{4}$, P. Serrano-Ortiz ${ }^{5}$, C. Oyonarte ${ }^{6}$, and A. S. Kowalski ${ }^{1,2}$ \\ ${ }^{1}$ Departamento de Física Aplicada, Facultad de Ciencias, Universidad de Granada, Fuentenueva s/n, 18071 Granada, Spain \\ ${ }^{2}$ Grupo de Física de la Atmósfera, Centro Andaluz de Medio Ambiente (CEAMA), 18006, Granada, Spain \\ ${ }^{3}$ Estación Experimental de Zonas Áridas, CSIC, 04001 Almería, Spain \\ ${ }^{4}$ Centro de Investigación del Fuego, Toledo, 45071, Spain \\ ${ }^{5}$ Department of Biology, University of Antwerpen, Wilrijk, Belgium \\ ${ }^{6}$ Departamento de Edafología y Química Agrícola, Universidad de Almería, Carrera Sacramento s/n, 04120, Almería, Spain
}

Received: 17 December 2009 - Published in Biogeosciences Discuss.: 26 January 2010

Revised: 29 July 2010 - Accepted: 2 August 2010 - Published: 3 September 2010

\begin{abstract}
Two years of continuous measurements of net ecosystem exchange (NEE) using the eddy covariance technique were made over a Mediterranean alpine shrubland. This ecosystem was found to be a net source of $\mathrm{CO}_{2}$ (+52 $\pm 7 \mathrm{~g} \mathrm{C} \mathrm{m}^{-2}$ and $+48 \pm 7 \mathrm{~g} \mathrm{C} \mathrm{m}^{-2}$ for 2007 and 2008) during the two-year study period. To understand the reasons underlying this net release of $\mathrm{CO}_{2}$ into the atmosphere, we analysed the drivers of seasonal variability in NEE over these two years. We observed that the soil water availability - driven by the precipitation pattern - and the photosynthetic photon flux density (PPFD) are the key factors for understanding both the carbon sequestration potential and the duration of the photosynthetic period during the growing season. Finally, the effects of the self-heating correction to $\mathrm{CO}_{2}$ and $\mathrm{H}_{2} \mathrm{O}$ fluxes measured with the open-path infrared gas analyser were evaluated. Applying the correction turned the annual $\mathrm{CO}_{2}$ budget in 2007 from a sink $\left(-135 \pm 7 \mathrm{~g} \mathrm{C} \mathrm{m}^{-2}\right)$ to a source $\left(+52 \pm 7 \mathrm{~g} \mathrm{C} \mathrm{m}^{-2}\right)$. The magnitude of this change is larger than reported previously and is shown to be due to the low air density and cold temperatures at this high elevation study site.
\end{abstract}

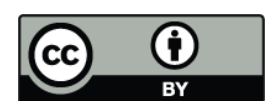

Correspondence to: A. S. Kowalski (andyk@ugr.es)

\section{Introduction}

The concentration of carbon dioxide and other greenhouse gases in the atmosphere has been increasing since the industrial revolution, and is believed to be causing global surface temperatures to rise (Forster et al., 2007). Global warming is a serious concern as it seems to be driving global climate change (IPCC, 2007). The consequences of climate change are far from being completely quantified, and of particular concern is its impact on terrestrial ecosystems.

In recent decades, the eddy covariance technique (Baldocchi, 2003) has emerged as one of the most reliable techniques for quantifying mass and energy exchange. The eddy covariance technique is currently applied worldwide covering many different terrestrial ecosystem types with the aim of understanding the positive or negative feedbacks that climate change will have on Earth's surface. These sites have been grouped into different continental networks assessing net ecosystem exchange (NEE) such as EUROFLUX (Aubinet et al., 2000), AmeriFlux (Pryor and Barthelmie, 1999), and ChinaFLUX (Yu et al., 2006), forming the global FLUXNET (Baldocchi et al., 2001). Nonetheless, gaps in knowledge regarding some ecosystems still lead to uncertainties in global assessments.

In this regard little is known about high altitude sites (Schimel et al., 2002). The mountain and alpine regions of the world cover 10\% of the Earth's terrestrial surface (Spehn and Körner, 2005). Understanding the patterns and drivers of NEE in these environments is very important for accurate determinations of the global carbon budget and for creating new

Published by Copernicus Publications on behalf of the European Geosciences Union. 
perspectives in policymaking (Mountain Research Initiative; Becker and Bugmann, 2001). However, there is scarce data available to parameterize or validate models on alpine shrublands.

The effect of climate change on the carbon balance of high altitude ecosystems is a pressing subject of debate (Becker and Bugmann, 2001). As global temperatures rise, an earlier snow melt results in longer growing seasons which may lead to increased carbon assimilation (Lafleur and Humphreys, 2007). However, this increase in the growing season may result in reduced carbon sequestration, as a result of water limitations (Hu et al., 2009). On the other hand, permafrost melt in the tundra, a consequence of rising temperatures, is enhancing soil microbial respiration to a larger degree than photosynthetic carbon assimilation (Oechel et al., 1993). Understanding the complexity of biosphere-atmosphere interactions and the drivers of seasonal changes in NEE in coldlimited, high altitude ecosystems is far from resolved, particularly for high-altitude shrublands, where eddy covariance measurements are still lacking.

Another factor adding uncertainty to NEE estimates of cold ecosystems is related to the anomalous downward $\mathrm{CO}_{2}$ fluxes observed during off-seasons (Amiro et al., 2006a, b; Grelle and Burba, 2007; Ono et al., 2008; Lafleur and Humphreys, 2007) or during snow covered periods when assessed by open-path eddy covariance (Skinner, 2007; Lafleur and Humphreys, 2007). Small photosynthesis rates $\left(<0.1 \mu \mathrm{mol} \mathrm{m}{ }^{-2} \mathrm{~s}^{-1}\right)$ have been observed over snowcovered vegetation (Starr and Oberbauer, 2003), if the snowpack is not too thick. However, the contribution of soil respiration through the snow cracks (soil temperatures are still high enough below the snowpack) should overcome any small uptake by photosynthesis (Musselman et al., 2005; Monson et al., 2006a). The recently-published Burba correction (Burba et al., 2008) rectifies such apparent net $\mathrm{CO}_{2}$ uptake. The relevance of the Burba correction for the accurate determination of the carbon balance in cold ecosystems remains controversial. It has been experimentally observed to be negligible at some sites (Haslwanter et al., 2009), but not elsewhere where caution has been urged in its use (Blanken et al., 2009).

In this study we present two years (2007 and 2008) of $\mathrm{CO}_{2}$ fluxes over a Mediterranean alpine shrubland. The general goals of this paper are: a) to identify the main variables driving the annual behaviour of NEE, b) to examine, focusing mainly on 2007, the explanations for seasonal and daily changes in NEE and c) to assess the role of the Burba correction for accurate measurements of the carbon balance.

\section{Experimental site description and methods}

\subsection{Site description}

The area of study is situated within an endorheic basin ( $2300 \mathrm{~m}$ a.s.l.) belonging to the Sierra Nevada mountain range, in the southeast of Spain $\left(37^{\circ} 05^{\prime} \mathrm{N} 2^{\circ} 57^{\prime} \mathrm{W}\right), 39 \mathrm{~km}$ from the Mediterranean coast. The basin is an ancient cirque stemmed by a moraine and subsequently remodeled in the glacial age (Sánchez et al., 1988). Mean annual precipitation is $800 \mathrm{~mm}$ and the mean annual temperature $5.5^{\circ} \mathrm{C}$ (Aguilar et al., 1986). The Sierra Nevada mountain range does not belong to the permafrost zone, however, certain processes occur that are also quite relevant to tundra: fluted and polygonal soils as a consequence of frosting and defrosting of the soil, and pipkrake processes (Gil-de-Carrasco et al., 1997). Furthermore, Prieto-Fernández (1975) describes vegetation species found in Sierra Nevada that are typical of arctic tundra. The site is usually snow covered from December to March. The subsequent snow melt causes water to flow across the basin and accumulate at the bottom creating a small lagoon that usually remains for approximately one month during the onset of the growing season. The flux tower is situated on a gentle slope separated from the lagoon by a fetch exceeding $150 \mathrm{~m}$.

Festuca indigesta and Cytisus purgans are the dominant plant species, reaching to $20 \mathrm{~cm}$ height and homogeneously covering $45 \%$ of the ground. A remaining 35\% corresponds to litter and $20 \%$ is bare soil. The presence of other plant species is intermittent throughout the year, and very sparse. Measurements of leaf area index (LAI), assessed with destructive methods, provided an average value of $1.23 \mathrm{~m}^{2} / \mathrm{m}^{2}$ which is approximately constant over the seasons.

The soil is composed of sand $(56 \%)$, silt $(30 \%)$ and clay (14\%) with a bulk density of $1110 \mathrm{~kg} \mathrm{~m}^{-3}$, determined in situ using soil cores. The permanent wilting point was estimated at a volumetric water content of $2.6 \%$. Soil organic matter ranged from $3.9 \%$ to $4.6 \%$ in the area around the flux tower. Soil analysis were conducted following recommendations from the American Society of Agronomy and Soil Science Society of America (Klute, 1986; Sparks, 1996).

\subsection{EC and meteorological and soil measurements}

Carbon dioxide and water vapor densities along with the 3 components of wind speed were measured at $20 \mathrm{~Hz}$ using an open-path infrared gas analyzer (IRGA, Li-7500, Lincoln, NE, USA) tilted ca. $12^{\circ}$ from the vertical (toward the north) and a sonic anemometer (USA-1, METEK, Elmshorn, Germany), mounted on a tower at $2.25 \mathrm{~m}$ above ground. Data were saved as 5-s averages, variances and covariances by a logger (METEK, Elmshorn, Germany) and subsequently converted to half-hour bases following Reynolds' rules. We applied 2-D coordinate rotations (McMillen, 1988; Kowalski et al., 1997), density corrections (Webb et al., 1980) and 
Table 1. Empirically determined linear relations used to estimate random errors $(\sigma)$ in fluxes as a function of the flux magnitude for the Laguna Seca field site (see Richardson et al., 2006). Resulting standard deviations were used to add artificial noise following a Laplace distribution. Every $R^{2}$ was greater than 0.83 .

\begin{tabular}{lcccc}
\hline & $\begin{array}{c}F_{\mathrm{C}}>0 \\
\mu \mathrm{mol} \mathrm{m}{ }^{-2} \mathrm{~s}^{-1}\end{array}$ & $\begin{array}{c}F_{\mathrm{C}}<0 \\
\mu \mathrm{mol} \mathrm{m} \mathrm{s}^{-1}\end{array}$ & $\begin{array}{c}\mathrm{LE}>0 \\
\mathrm{~W} \mathrm{~m}^{-2}\end{array}$ & $\begin{array}{c}\mathrm{LE}<0 \\
\mathrm{~W} \mathrm{~m}^{-2}\end{array}$ \\
\hline 2007 Burba & $0.80+0.042 \mathrm{FC}$ & $0.79-0.061 \mathrm{FC}$ & $15+0.12 \mathrm{LE}$ & $15+0.035 \mathrm{LE}$ \\
2007 & $0.74+0.068 \mathrm{FC}$ & $0.89-0.12 \mathrm{FC}$ & $9.6+0.18 \mathrm{LE}$ & $7.7-0.044 \mathrm{LE}$ \\
2008 Burba & $0.81+0.056 \mathrm{FC}$ & $0.81-0.073 \mathrm{FC}$ & $17+0.13 \mathrm{LE}$ & $16-0.25 \mathrm{LE}$ \\
2008 & $0.69+0.058 \mathrm{FC}$ & $0.69-0.069 \mathrm{FC}$ & $14+0.17 \mathrm{LE}$ & $12-0.21 \mathrm{LE}$ \\
\hline
\end{tabular}

the Burba correction (Burba et al., 2008; Järvi et al., 2009) as well as quality control checks with home-made MATLAB routines. The IRGA was calibrated bimonthly (except when weather limited site access) with gas standards of $\mathrm{N}_{2}$ for zero and $479.5 \mathrm{ppm}$ as a span $\mathrm{CO}_{2}$ reference.

Air temperature and humidity were measured by a thermohygrometer (STH-5031, Geonica, Madrid, Spain) at $1.5 \mathrm{~m}$ above the ground. Incident and reflected photosynthetic photon flux densities (PPFD) were measured by two quantum sensors (Li-190, Li-cor, Lincoln, NE, USA), also at $1.5 \mathrm{~m}$. Net radiation was measured with a net radiometer (CN1-R, Middleton Solar, Brunswick, Australia) at $1 \mathrm{~m}$ above the surface. Rainfall was measured by a tipping bucket $(0.2 \mathrm{~mm})$ rain gauge (PLUVIOM 52203, RM Young, Traverse city, MI, USA). Three temperature and soil water content (EC20, ECH2O, Decagon Devices, Pullman, WA, USA) sensors were also installed at $4 \mathrm{~cm}$ depth under both bare soil and plant cover having a sensitivity of $0.1{ }^{\circ} \mathrm{C}$ and $0.2 \%$, respectively. These measurements were made at $1 \mathrm{~Hz}$, but then averaged to $10 \mathrm{~min}$ and stored in data loggers (Meteodata 3000c, Geonica).

\subsection{Data quality control, gap filling and statistical analysis}

The 5-s data that did not satisfy a de-spiking routine were eliminated. Half-hours statistics were not computed when eliminated data exceeded $25 \%$ of the total. The subsequent processed half-hour statistics were also excluded from further analysis when rain or condensation (including frequent fog or dew) caused poor performance of the open-path IRGA. Nighttime data below the $u_{*}$ threshold of $0.2 \mathrm{~m} \mathrm{~s}^{-1}$ were also rejected for not fulfilling the turbulence measurement premise (Carrara et al., 2003; Wohlfahrt et al., 2005). This threshold was determined by plotting the nighttime $\mathrm{CO}_{2}$ flux versus $u_{*}$, and determining a value above which there was no dependence as described by Goulden et al. (1996). There were $16 \%$ and $20 \%$ of gaps in the 2007 and 2008 datasets due to electronic malfunction, calibration, power outages and poor performance of the anemometer and Li7500 during inclement meteorological conditions. Nights with low turbulence resulted in $11 \%$ and $9 \%$ of data removed from 2007 and 2008 dataset. Finally, 6\% and 3\% were also rejected respectively from the two years due to spikes on half-hour timescales, yielding a total gap fraction of $33 \%$ and $32 \%$. To obtain a continuous dataset for assessing the annual NEE, data were gap-filled following Falge et al. (2001) and Reichstein et al. (2005; http://gaia.agraria.unitus.it/database/ eddyproc/index.html).

\subsection{Uncertainty analysis}

An uncertainty analysis established confidence intervals for $\mathrm{CO}_{2}$ and water vapor balances. Random uncertainty and errors introduced by the gap-filling process were jointly calculated by realizing Monte Carlo simulations (Richardson and Hollinger, 2007). First, normally distributed random gaps were created in continuous annual datasets. Second, artificial noise was added to the remaining data following a Laplace distribution with a site-specific standard deviation that scaled with the magnitude of the $\mathrm{CO}_{2}$ and water vapor fluxes (see Table 1; Richardson et al., 2006). Finally, these synthetic datasets were gap-filled so that different annual sums were obtained. Twice the standard deviation of such sums was taken as our annual error.

\subsection{Respiration fitting}

Nighttime $\mathrm{CO}_{2}$ fluxes were fitted to the model following Raich and Schlesinger (1992):

$R_{\mathrm{eco}}=R_{\mathrm{ref}} Q_{10}^{\frac{T_{\mathrm{s}}-T_{\mathrm{ref}}}{10}}$

where $R_{\text {eco }}$ corresponds to the ecosystem respiration, $R_{\text {ref }}$ is the respiration at the reference temperature ( $\left.T_{\text {ref }}\right), Q_{10}$ corresponds to the change in $R_{\text {eco }}$ for a $10^{\circ} \mathrm{C}$ change in temperature and $T_{\mathrm{S}}$ is the soil temperature. The reference temperature was chosen as $8^{\circ} \mathrm{C}$, which is close to the annual mean temperature. 


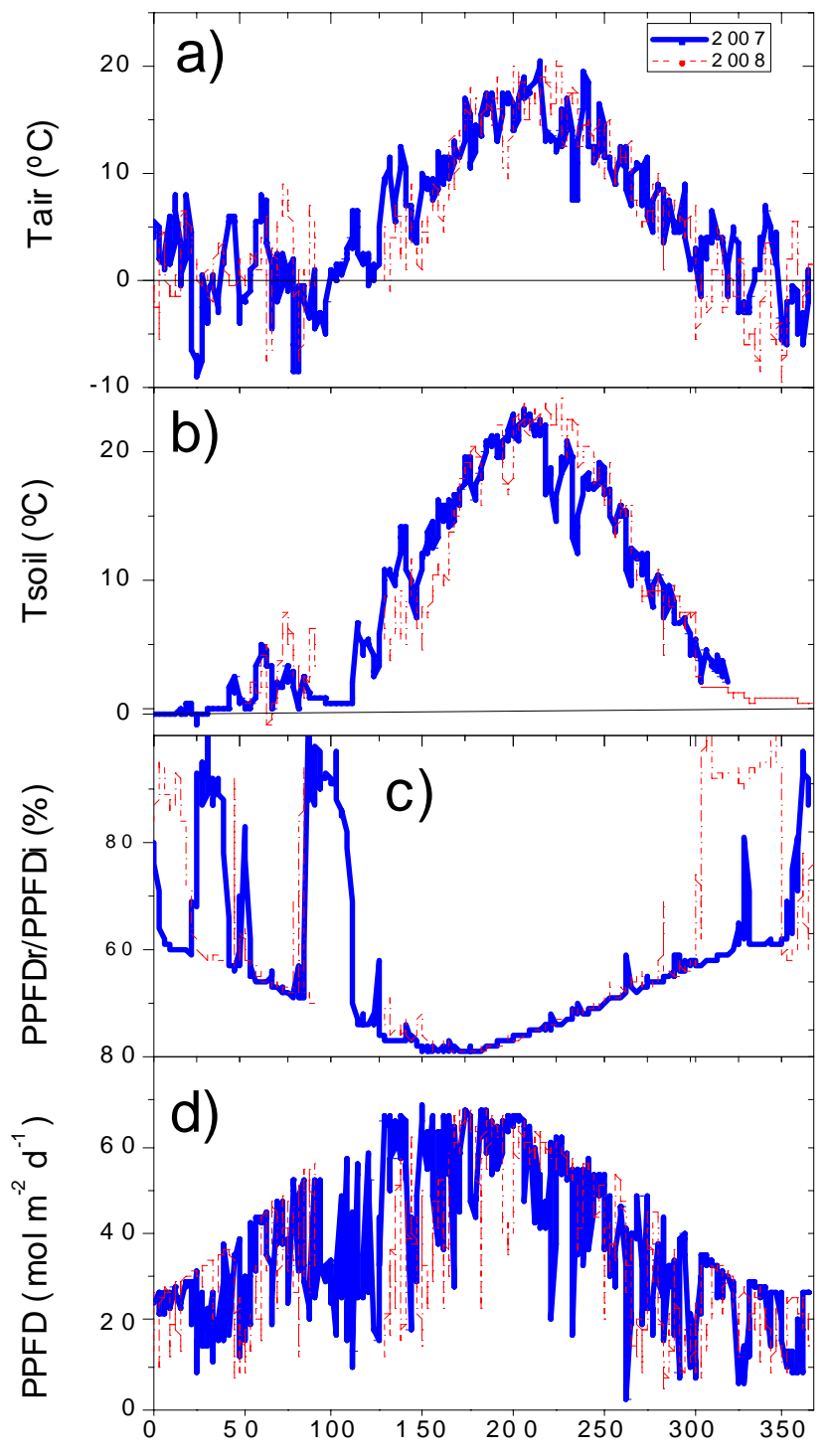

Day of the year

Fig. 1. Average daily environmental conditions in the alpine Mediterranean shrubland located in Sierra Nevada mountain range (southeast of Spain): (a) air temperature, (b) soil temperature, (c) ratio of reflected to incident photosynthetic photon flux density, (d) absorbed photosynthetic photon flux density.

\section{Results and discussion}

\subsection{Meteorological conditions in 2007 and 2008}

Both years showed very similar patterns of air and soil temperature and PPFD (Fig. 1a, b and c). In fact, annual mean air temperature was $5.8^{\circ} \mathrm{C}$ in both years and PPFD averaged $435 \mu \mathrm{mol} \mathrm{m} \mathrm{m}^{-2} \mathrm{~s}^{-1}$ in 2007 and $410 \mu \mathrm{mol} \mathrm{m}^{-2} \mathrm{~s}^{-1}$ in 2008. Annual rainfall was $402 \mathrm{~mm}$ in 2007 and $390 \mathrm{~mm}$ in 2008 .

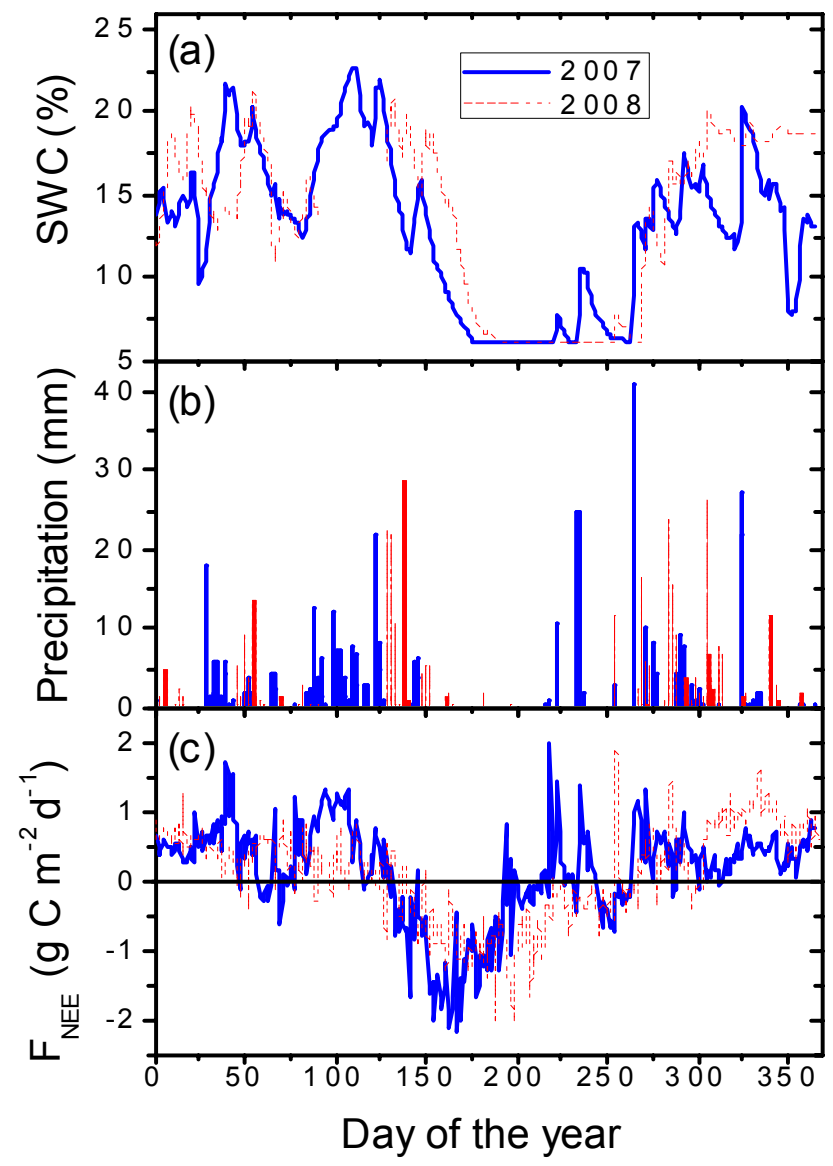

Fig. 2. Average daily environmental conditions in the Mediterranean alpine shrubland located in the Sierra Nevada mountain range (southeast Spain): (a) soil water content, (b) precipitation and (c) net ecosystem exchange flux. The Burba correction was applied.

Our precipitation measures are likely underestimated during winter, since rain gauges are not designed to measure solid precipitation. Furthermore, thirty-seven days of rain-gauge measurements were missing during 2008, due to instrument malfunction and inclement weather $(25 \mathrm{~mm}$ were measured during this missing period at a station $12 \mathrm{~km}$ distant). However, soil water content (SWC) at the end of this 37-day period (DOY 129) was comparable for both years $(12.6 \%$ for 2007 , and $13.6 \%$ for 2008), suggesting that precipitation, at least during the last days of this period, was comparable.

\subsection{Winter/spring dynamics and the onset of the first growing season}

Although little differences were apparent in annual temperature or precipitation, we did observe important differences at seasonal and weekly scales, which developed into large annual NEE differences. For instance, some snow fall events (Fig. 1d), assessed via the reflected/incident PPFD ratio, occurred at different times of the year, and nearly three times 
as much rain fell during summer in $2007(42 \mathrm{~mm})$ as in 2008 (15 mm; Fig. 2b).

Differences in the time courses of precipitation and temperature appear to have affected the onset of the growing season as reflected in the temporal trends in NEE for both years (Fig. 2c). The low values of NEE between the days 70 and 77 seem to indicate an early onset of the growing season in 2007. However, a sudden rainfall (Fig. 2b) on day 78, enhancing soil respiration, and subsequent considerable snow cover that began day 85 , prevented growth development (see Fig. 3). Indeed, favourable synoptic weather conditions in early spring (days 125 to 150 ) appear to be fundamental, marking the onset of the growing season and the transition from source to sink of $\mathrm{CO}_{2}$.

The two years also presented different patterns in snow fall and snow cover to which we attribute differences in NEE during the days 77 to 110 . During this time, air temperature and PPFD were much higher in 2007 than in 2008 (Fig. 1a and c), probably due to decreased cloudiness in the 2007 early spring. Although the transition from source to sink of $\mathrm{CO}_{2}$ happens between days 125-150 in both years, the strength of the $\mathrm{CO}_{2}$ sink is higher in 2007 than in 2008. This indicates that air temperature and PPFD are key variables driving the onset of the growing season. Water availability is seldom a limiting factor during the alpine Mediterranean spring (SWC was much higher than the permanent wilting point, around $15.4 \%$ in 2007 and $15.7 \%$ in 2008). In fact, there was more rainfall and therefore higher SWC in 2008, as compared to 2007 (Fig. 2a and b) in this period, which supports the notion that temperature and PPFD, and not precipitation, control the onset of the growing season. Maximum daily $\mathrm{CO}_{2}$ uptake in 2007 was $-2.2 \mathrm{~g} \mathrm{C} \mathrm{m}^{-2}$, and took place around mid June (DOY 167), whereas maximum daily $\mathrm{CO}_{2}$ uptake in 2008 was lower $\left(-2 \mathrm{~g} \mathrm{C} \mathrm{m}^{-2}\right)$ and happened approximately one month later (Fig. 2c).

\subsection{Summer dynamics and the end of the first growing season}

Maximum ecosystem carbon assimilation occurred during mid June (DOY 167) and mid July (DOY 200) in 2007 and 2008 respectively. During this period, the ecosystem was characterized by mild air temperatures and high PPFD, which would favour the photosynthetic period to continue. However, after that time the lack of water resources (Fig. 2a and $b$ ), which arises from the typical summer drought in the Mediterranean, starts to limit photosynthetic activity, and strongly constrains NEE (Fig. 2c).

\subsection{Autumn dynamics and the onset of the second grow- ing season}

The lack of water resources limits biological activity by the mid and late summers (from DOY 163 and 200 on) of 2007 and 2008, respectively. Even so, some photosynthesis con-
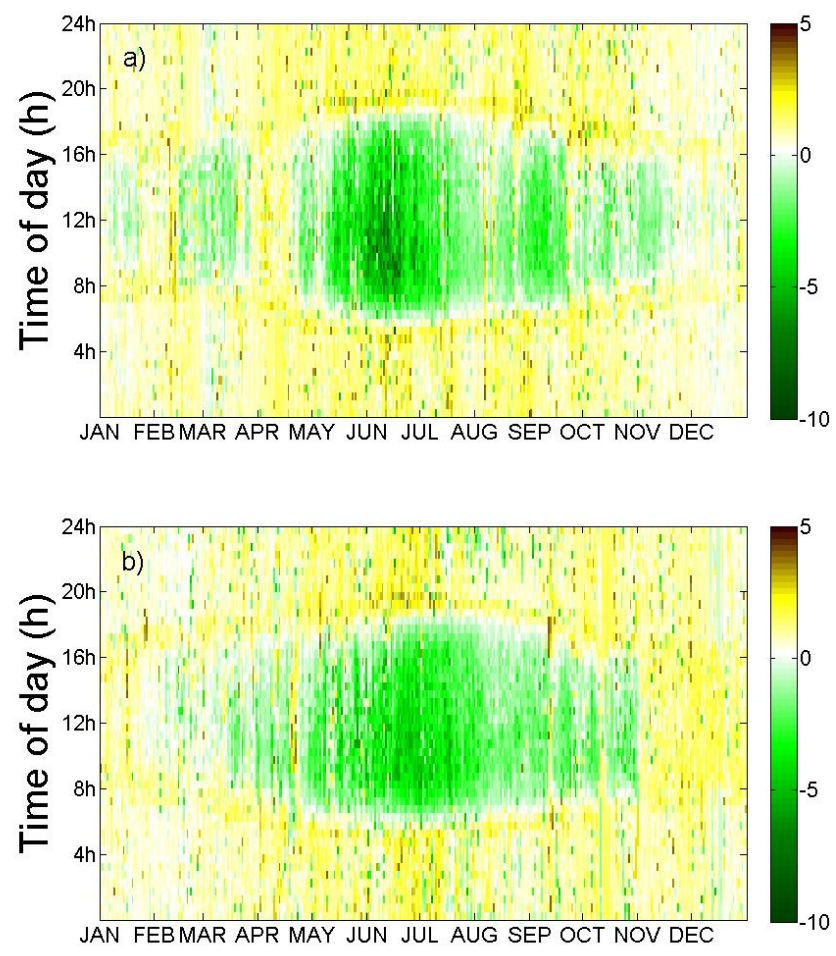

Fig. 3. Annual and daily evolution of NEE $\left(\mu \mathrm{mol} \mathrm{m} \mathrm{m}^{-2} \mathrm{~s}^{-1}\right)$ by the alpine Mediterranean shrubland located in the Sierra Nevada mountain range during (a) 2007 and (b) 2008.

tinues, as hydrological resources from the soil water stock are still available. This trend continues until the last days of summer when the first rains come after a long dry period. These autumn rains were accompanied by soil remoistening (Fig. 2a and b) that activated heterotrophic respiration, causing large, sudden releases of carbon (Huxman et al., 2004). These new water inputs ease plant stress and foster tissue repair and rehydration in the days following rainfall (Sala et al., 1982). Such plant recovery, which may last up to 7 days (Sala et al., 1982), pushes NEE negative again, starting a second growing season (around day 250 of Fig. 2c). This phenomenon is characteristic of Mediterranean climates (Wohlfahrt et al., 2008a) where the first rains after a long drought period usually arrive either in the last days of the summer or in the first days of autumn, and summer-like meteorological conditions continue afterwards for a while (the so-called Veranillo de San Miguel). The extended sunny period that favoured the second growing season of 2007, right after the first summer/autumn rains, did not take place during 2008.

\subsection{Diurnal and monthly differences between 2007 and 2008}

Some diurnal differences are encountered between the two years. Figure $3 a$ and $b$ represents the daily evolution of NEE throughout the year 2007 and 2008, respectively. We found 


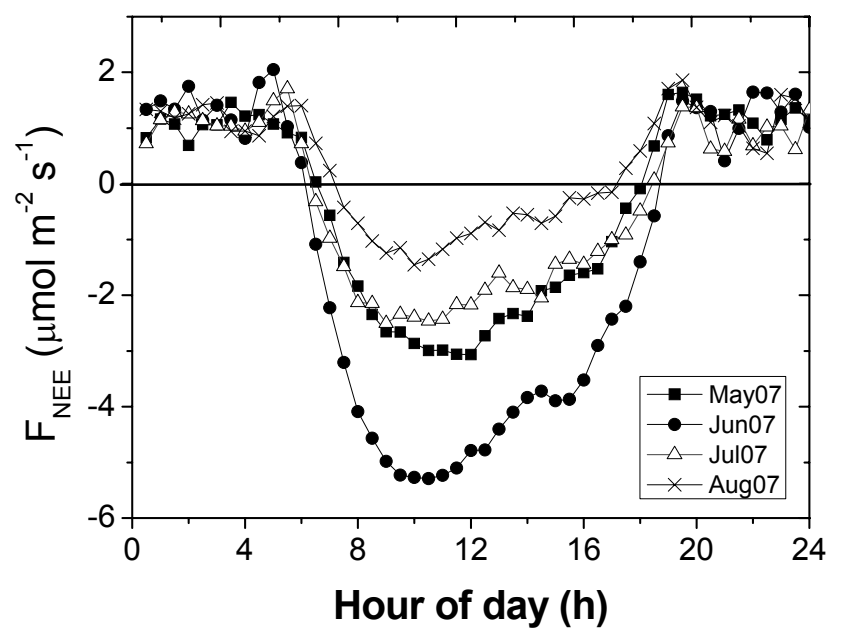

Fig. 4a. Mean diurnal NEE flux during May, June, July and August 2007 in the alpine Mediterranean shrubland located in Sierra Nevada mountain range.

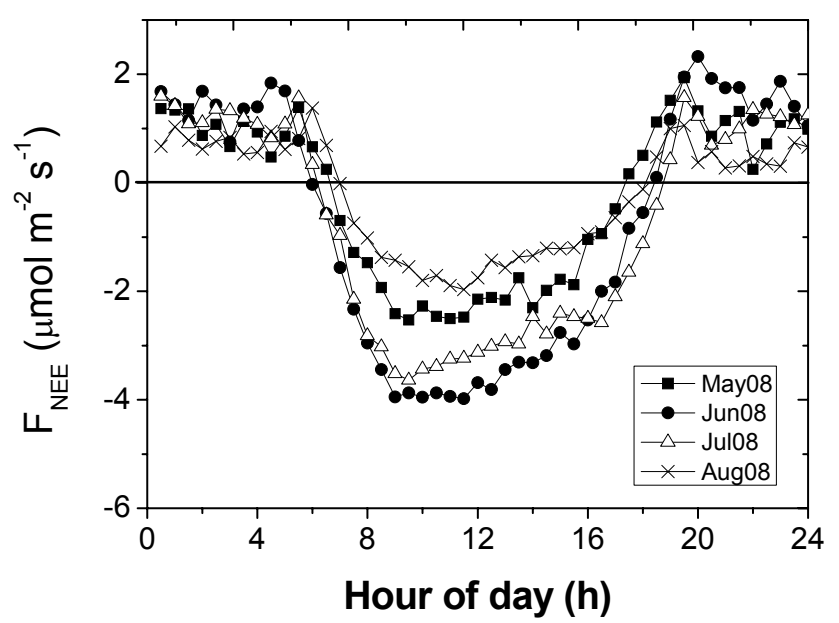

Fig. 4b. Mean diurnal NEE flux during May, June, July and August 2008 in the alpine Mediterranean shrubland located in Sierra Nevada mountain range.

that $\mathrm{CO}_{2}$ uptake follows PPFD throughout each year, except during precipitation or water stress, which alter the relationship between PPFD and NEE. The same figure also displays asymmetry in NEE around noon. A higher daily uptake, peaking around $10 \mathrm{~h}$, is found in 2007 and between $9 \mathrm{~h}$ and $12 \mathrm{~h}$ in 2008. The means for months of higher photosynthetic activity are displayed in Fig. 4, which further shows such asymmetry: maximum uptake before noon and subsequent NEE reduction in the afternoon. This afternoon depletion may also be observed in the daily relationship between NEE and PPFD, such that NEE was more negative for a given level of PPFD in the morning than in the afternoon (Fig. 5), representing hysteresis. This could be due to a series of interacting factors, which may be viewed as either environmen-

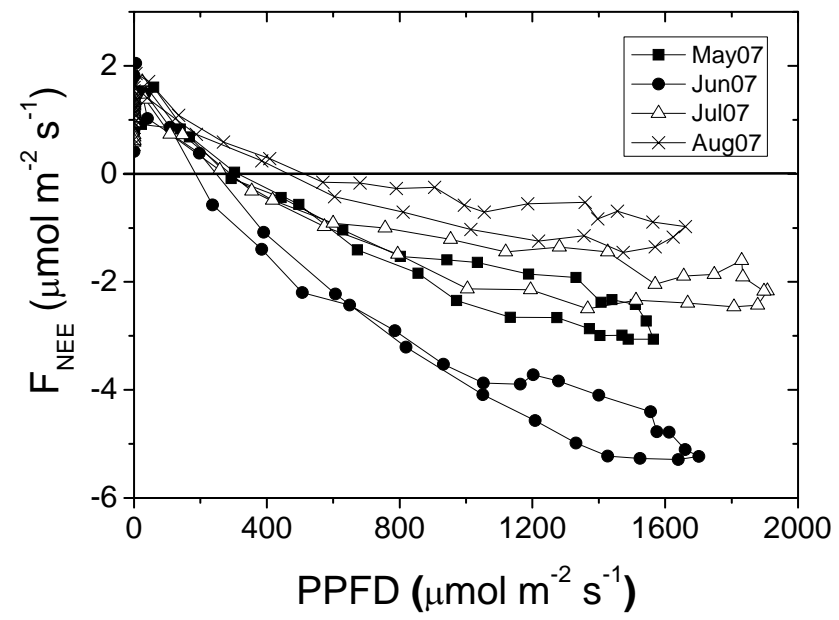

Fig. 5a. Mean hourly NEE flux vs. PPFD during May, June, July and August 2007. Hysteresis was found for every month, with the temporal trend proceeding counterclockwise.

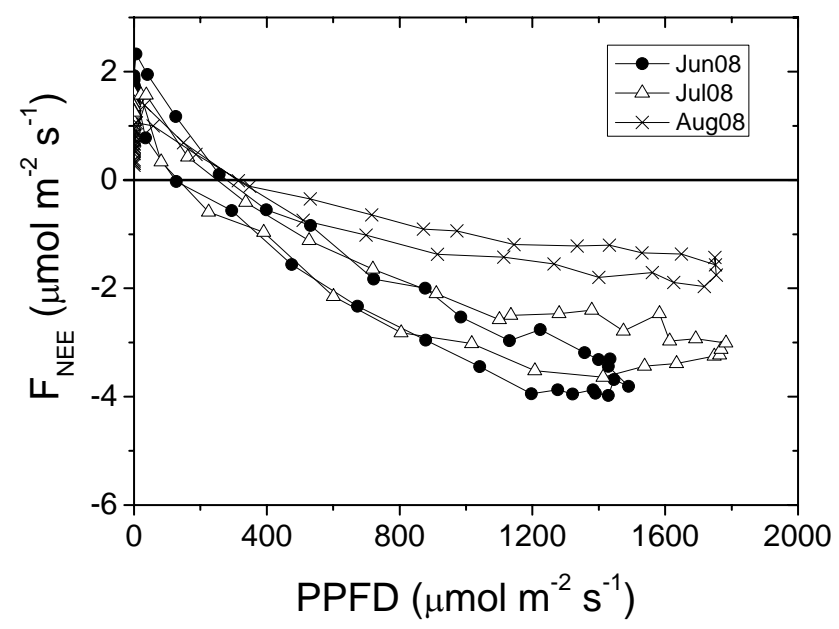

Fig. 5b. Mean hourly NEE flux vs. PPFD during June, July and August 2008. Hysteresis was found for every month, with the temporal trend proceeding counterclockwise. May was removed for lack of data.

tal or endogenous (that is, resulting from plant behaviour). Temperature is typically higher in the afternoon than in the morning for a given level of PPFD, which could stimulate soil respiration. Figure 6a displays different nocturnal respiration trends as a function of temperature for different classes of SWC. We found positive exponential trends for every SWC class $\left(R^{2}=0.56\right.$ for SWC $>18 \%, R^{2}=0.80$ for $12 \%<$ SWC $<18 \%$ and $R^{2}=0.51$ for $8 \%<$ SWC $<12 \%$ ) except for the lowest values (SWC $<8 \%$ ), for which warming, such as that in the afternoon, does not increase soil respiration. When the light-response curve (Fig. 6b) is plotted for such a dataset (SWC $<8 \%$ ) a clear hysteresis cycle is observed. Thus, afternoon NEE reduction appears not to be 
due exclusively to an enhancement of soil respiration in the afternoon.

There are several factors that can potentially interact to shape the observed hysteresis in the NEE-PPFD relationship. First, as the Bowen ratio and VPD increase at midday, stomatal conductance drops to avoid runaway cavitation (Tyree and Sperry, 1988), at the expense of diminishing carbon uptake. Water stored within the stem xylem diminishes during the day such that, after midday stomatal closure, plants are not fully capable of recovering the level of stomatal conductance they had in the morning (Sperry et al., 2008; Hölttä et al., 2009). Second, the accumulation of sugars within a leaf may lead to a feedback inhibition of rubisco activity (Lambers et al., 1998). Third, daily patterns of carbon assimilation have been shown to undergo circadian regulation, such that plants are "programmed" to have a higher carbon uptake in the morning than in the afternoon, independent of environmental factors (Webb, 2003; Dougthy et al., 2006; Resco et al., 2009). Canopy conductance, computed using the Penman-Monteith equation (Jones, 1992), shows a slight decrease during the afternoon (data not shown), corresponding to the decrease in carbon uptake evident in the light response curve of Figs. 5 and $6 \mathrm{~b}$ (hysteresis).

\subsection{Annual differences between 2007 and 2008}

Differences in the length and strength of the growing season and in the timing of the rain and snow fall seem to be responsible for general NEE disparities between the two years. The study site is a net source of $\mathrm{CO}_{2}$ during both years. Annual emissions of $\mathrm{CO}_{2}$ were $+52 \pm 7 \mathrm{~g} \mathrm{C} \mathrm{m}^{-2}$ and $+48 \pm 7 \mathrm{~g} \mathrm{C}^{-}$ $\mathrm{m}^{-2}$ for 2007 and 2008, respectively. These differences are due mainly to disparities in carbon uptake during the growing season. The growing season of 2007 was shorter and more skewed than that of 2008 (Fig. 2c). It lasted longer in 2008 and presented a less steep slope, but ultimately with less area and therefore less $\mathrm{CO}_{2}$ uptake. Rain pulse events following long dry periods took place in both years bringing about large emissions, but in different amounts depending on their timing. Both years presented large releases during the first 125 days contributing to the annual source of carbon. Each of three events of snowfall and thawing during these 125 first days of 2007 (Fig. 1d) may have contributed to net release (Monson et al., 2006a). Snow inhibits the photosynthetic activity covering the vegetation leaves, but not bacterial processes since the snow cover prevents soil temperature from falling excessively (Monson et al., 2006b). During snowcovered periods respiration is expected to dominate NEE, and therefore the timing of snows-thaws may also account for annual differences between the two years.

Our Mediterranean alpine site was a carbon source for both 2007 and 2008. It may be that high-altitude ecosystems are undergoing a $\mathrm{CO}_{2}$ uptake depletion in the same manner as tundra sites (Oechel et al., 1993). The study site may have been a carbon sink in previous years, but the rise of the mean

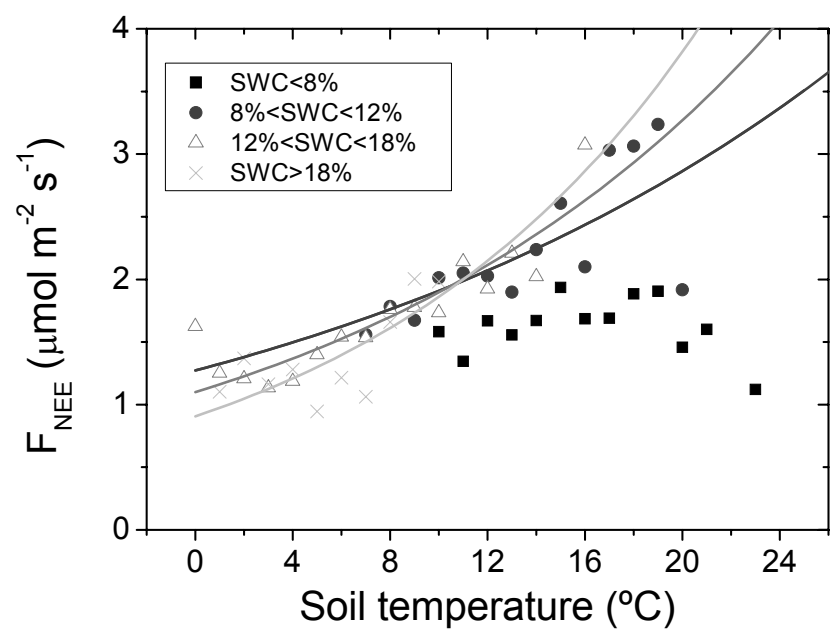

Fig. 6a. Mean nocturnal NEE in 2007 vs. soil temperature for different soil water contents classes. Three classes of SWC (those for $\mathrm{SWC}>8 \%$ ) were fitted to exponential dependency with soil temperature (fine line: $\mathrm{SWC}>18 \%$; medium line: $12 \%<\mathrm{SWC}<18 \%$; dark line: $8 \%<\mathrm{SWC}<12 \%$ ). No good agreement was found for $\mathrm{SWC}<8 \%$.

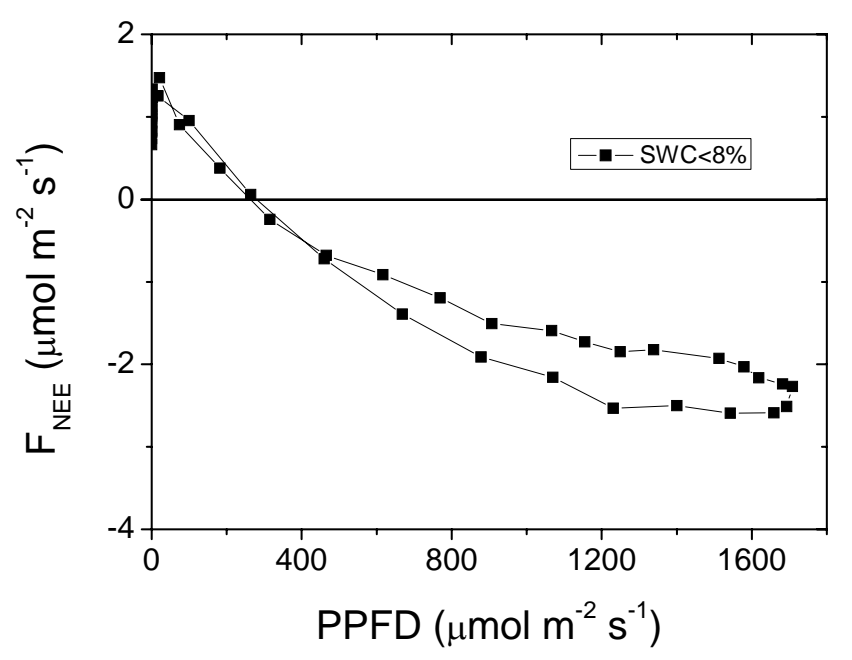

Fig. 6b. Mean hourly NEE flux vs. PPFD for SWC $<8 \%$ in 2007 . Clear hysteresis was found for lowest SWC values. NEE flux for the lowest values of SWC does not present any increasing relationship with temperature (Fig. 6a), however, it does present a clear hysteresis cycle indicating that afternoon soil temperature enhancement (and soil respiration with it) is not the consequence of hysteresis.

global temperature and reallocation of the rain patterns as a consequence of climate change might have caused a positive feedback, at least temporarily, turning our ecosystem into a net carbon source. There is therefore a pressing need to develop longer time series to address how alpine shrublands may respond to climate change. 


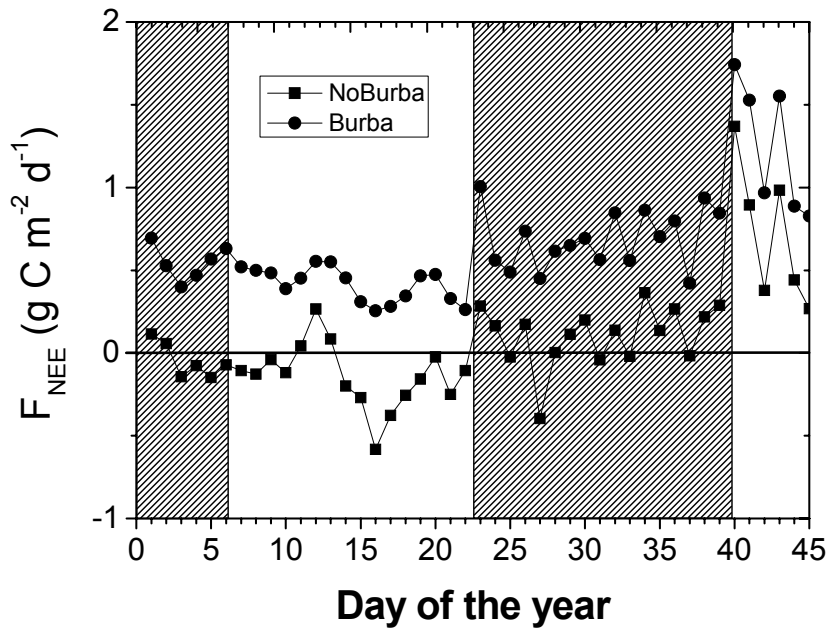

Fig. 7. The NEE flux during the first 45 days of 2007. Black line with squared points is the NEE flux with no correction. Black line with round points is the same NEE but corrected. Shades areas show periods when the ecosystem was snow-covered. Some snowed days have an apparent downward $\mathrm{CO} 2$ flux when not correction was applied. The NEE flux corrected from Burba is always above the non-corrected one.

\subsection{The Burba correction}

Although some have claimed the Burba correction to be negligible (Haslwanter et al., 2009) or even problematic (Wohlfahrt et al., 2008b), we found it to be very important for our experimental site. Figure 7 shows daily NEE with and without the correction during the first weeks of 2007. The shaded areas indicate periods of snow cover. It is evident that the final Burba-corrected $\mathrm{CO}_{2}$ flux is larger than the uncorrected $\mathrm{CO}_{2}$ flux. During the first week-long snow period, an apparent net uptake of $0.38 \mathrm{~g} \mathrm{C} \mathrm{m}^{-2}$ is corrected to yield an emission of $3.8 \mathrm{~g} \mathrm{C} \mathrm{m}^{-2}$, which seems much more reasonable as the average air temperature during these 7 days was just $3.4^{\circ} \mathrm{C}$ and the ecosystem was completely snow covered. A second snowfall took place on day 23 , where noncorrected values estimated six days of implausible uptake, which disappears once the correction is applied.

The Burba correction eliminates apparent uptake, and also introduces a positive increment that strongly affects longterm integrations. In fact, it is so important as to reverse conclusions regarding the annual $\mathrm{CO}_{2}$ source/sink behaviour. Figure 8a displays the cumulative NEE throughout the year 2007 , yielding $-135 \pm 7 \mathrm{~g} \mathrm{C} \mathrm{m}^{-2}$ without correction versus a source of $52 \pm 7 \mathrm{~g} \mathrm{C} \mathrm{m}^{-2}$ when applying the Burba considerations. For the year 2008 applying the Burba correction converted an annual $\mathrm{CO}_{2}$ sink of $-100 \pm 7 \mathrm{~g} \mathrm{C} \mathrm{m}^{-2}$ to a source of $48 \pm 7 \mathrm{~g} \mathrm{C} \mathrm{m}^{-2}$ (data not shown). Thus there is an increment in estimated annual carbon loss of $187 \pm 14 \mathrm{~g}$ $\mathrm{C}$ year $^{-1}$ in 2007 and $148 \pm 14 \mathrm{~g} \mathrm{C}$ year $^{-1}$ in 2008 when the correction is applied. This annual magnitude of the Burba

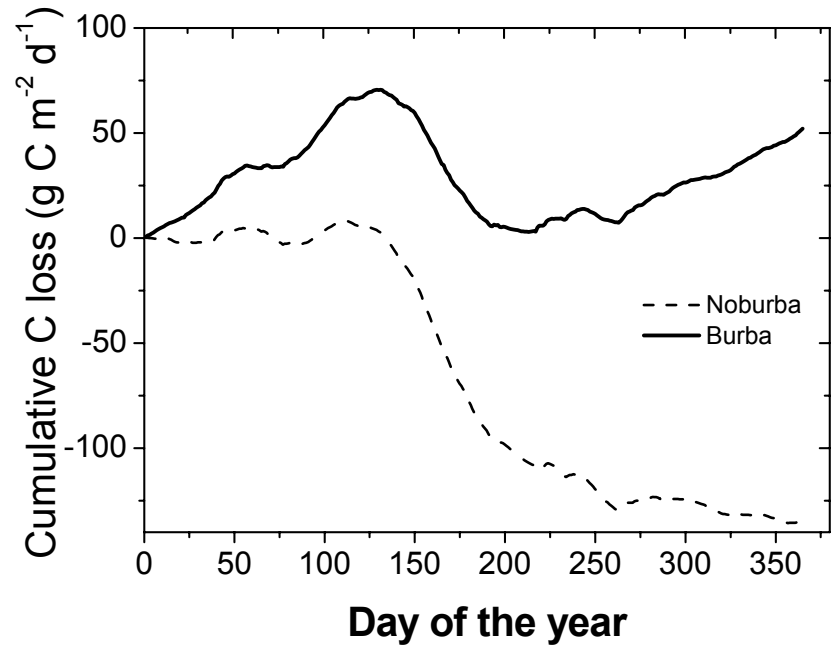

Fig. 8a. Cumulative net ecosystem exchange $\left(\mathrm{g} \mathrm{C} \mathrm{m}^{-2}\right)$ through the year 2007 (dashed line without and black line with the Burba correction applied).

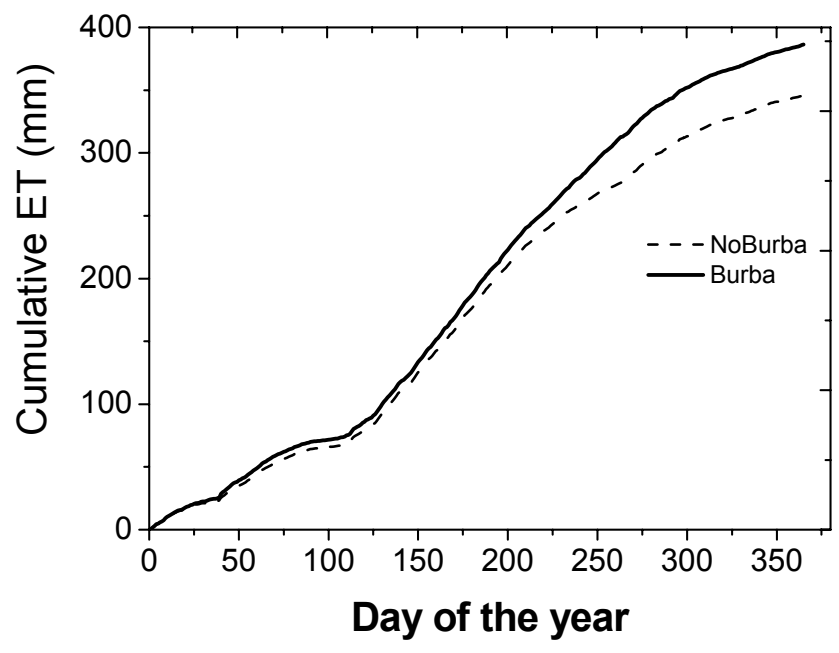

Fig. 8b. Cumulative evapotranspiration $(\mathrm{mm})$ throughout the year 2007 (dashed line without and black line with the Burba correction applied).

correction, higher than those previously reported (Burba et al., 2008), is due to the fact the site is at $2300 \mathrm{~m}$ elevation. For such an elevation, the $30 \%$ reduction in air density (and thereby heat capacity), means that instrument heating causes higher perturbations in temperature and density effects. Furthermore, cool or even cold summer nights at such elevation cause the Burba correction to be non-negligible for all seasons.

Figure $8 \mathrm{~b}$ shows cumulative evapotranspiration (ET) for the year 2007. In contrast to the case for cumulative NEE, the effect of applying the correction changes to a lesser extent. The corrected data yield an annual ET of $386 \pm 6 \mathrm{~mm}$, versus a non-corrected value of $346 \pm 5 \mathrm{~mm}$. 
These small differences in ET are similarly reflected at daily timescales (typically ranging between $1 \times 10^{-5}$ and $2 \times 10^{-4} \mathrm{~g} \mathrm{~m}^{-2} \mathrm{~s}^{-1}$ ). Because $\Delta \mathrm{ET} / \mathrm{ET}$ is 100 times lower than $\Delta \mathrm{F}_{\mathrm{CO} 2} / \mathrm{F}_{\mathrm{CO} 2}$, the importance of the Burba correction for ET on an annual basis is quite small compared to NEE, consistent with the findings of Burba et al. (2008). Therefore, the importance of the correction in ET on an annual basis is quite small if compared to NEE.

\section{Conclusions}

Seasonal variability in NEE at this high-altitude ecosystem seems to be mainly driven by the interaction between PPFD and precipitation/snow and to some extent by one or more environmental or endogenous factors on daily timescales. When snow covers the site, respiration dominates over photosynthetic processes. During spring when snow melts, moistening soil and roots, increases in temperature and PPFD drive the beginning of the growing season. At this point fair weather conditions are fundamental for development of the growing season, not only for high uptake rates but also for enduring uptake. The lack of water resources in the soil likely halts the growing season, thus reducing the uptake period. From then on, water limitation is the major driver of carbon fluxes (Granier et al., 2007) until the first rains arrive after a dry summer. Once the soil is remoistened, large respiration rates occur followed by a second uptake season during late summer or early fall if meteorological conditions permit. Hysteresis was found in the light response curves that we attributed to endogenous or environmental factors or to both of them (see Sect. 3.5).

Although some have found a negligible effect when applying the Burba correction, it may have profound impacts on annual budgets due to daily systematic error propagation (Moncrieff et al., 1996). Such bias may not be evident for ecosystems with great $\mathrm{CO}_{2}$ exchange potential, but large relative changes are observed here. The Burba correction strongly affects annual NEE of $\mathrm{CO}_{2}$, converting conclusions about the system from sink to source, but influencing the annual ET budget to a far lesser extent. Apparently, this correction is necessary for achieving credible carbon exchange measurements in very cold conditions, particularly for ecosystems with near-neutral capacity as carbon sources/sinks.

Acknowledgements. This research was supported by the regional government Junta de Andalucía, project BACAEMÁ (RNM-332) and the Spanish National flux tower network CARBORED-ES (CGL2006-14195-C02-01/CLI). We thank Regino Zamora, the Sierra Nevada National Park for infrastructure funding and logistical support, and the "Estación Experimental de Zonas Áridas" (EEZA-CSIC) for their close collaboration in this project. We thank George Burba for his impartial and significant remarks. VR was partly funded by the European Social Fund.

Edited by: G. Wohlfahrt

\section{References}

Aguilar, J., Simon, M., Medina, J., Gil de Carrasco, C., and Marañés, A.: Mapa de suelos a escala 1:10.000 y memoria explicativa de la hoja de Aldeire, Proyecto LUCDEME, 1986.

Amiro, B., Orchansky, A., and Sass, A.: A perspective on carbon dioxide flux measurements using an open-path infrared gas analyzer in cold environments, $27^{\text {th }}$ Conference on Agricultural and Forest Meteorology, American Meteorological Society, 2006a.

Amiro, B. D., Barr, A. G., Black, T. A., Iwashita, H., Kljun, N., McCaughey, J. H., Morgenstern, K., Murayama, S., Nesic, Z., Orchansky, A. L., and Saigusa, N.: Carbon, energy and water fluxes at mature and disturbed forest sites, Saskatchewan, Canada, Agricultural and forest meteorology, 136, 237-251, $2006 b$.

Aubinet, M., Grelle, A., Ibrom, A., Rannik, Ü., Moncrieff, J., Foken, T., Kowalski, A. S., Martin, P. H., Berbigier, P., Bernhofer, C., Clement, R., Elbers, J., Granier, A., Grünwald, T., Morgenstern, K., Pilegaard, K., Rebmann, C., Snijders, W., Valentini, R., and Vesala, T.: Estimates of the annual net carbon and water exchange of forests: the EUROFLUX methodology, Adv. Ecolog. Res., 30, 113-175, 2000.

Baldocchi, D., Falge, E., Gu, L., Olson, R., Hollinger, D., Running, S., Anthoni, P., Bernhofer, C., Davis, K., Evans, R., Fuentes, J., Goldstein, A., Katul, G., Law, B., Lee, X., Malhi, Y., Meyers, T., Munger, W., Oechel, W., Paw, K. T., Pilegaard, K., Schmid, H. P., Valentini, R., Verma, S., Vesala, T., Wilson, K., and Wofsy, S.: FLUXNET: A new tool to study the temporal and spatial variability of ecosystem-scale carbon dioxide, water vapor, and energy flux densities, B. Am. Meteorol. Soc., 82, 2415-2434, 2001.

Baldocchi, D. D.: Assessing the eddy covariance technique for evaluating carbon dioxide exchange rates of ecosystems: past, present and future, Global Change Biol., 9, 479-492, 2003.

Becker, A. and Bugmann, H.: Global change and mountain regions: The Mountain Research Initiative, IGBP Report NO.49. Stockholm, Sweden, 2001.

Blanken, P. D., Williams, M. W., Burns, S. P., Monson, R. K., Knowles, J., Chowanski, K., and Ackerman, T.: A comparison of water and carbon dioxide exchange at a windy alpine tundra and subalpine forest site near Niwot Ridge, Colorado, Biogechemistry, 95, 61-76, 2009.

Burba, G. G., Mcdermitt, D. K., Grelle, A., Anderson, D. J., and Xu, L.: Addressing the influence of instrument surface heat exchange on the measurements of $\mathrm{CO}_{2}$ flux from open-path gas analyzers, Global Change Biol,, 14, 1854-1876, 2008.

Carrara, A., Kowalski, A. S., Neirynck, J., Janssens, I. A., CurielYuste, J., and Ceulemans, R.: Net ecosystem $\mathrm{CO}_{2}$ exchange of mixed forest in Belgium over 5 years, Agric. For. Meteorol., 119, 209-227, 2003.

Dougthy, C. E., Goulden, M. L., Miller, S. D., and da Rocha, H. R.: Circadian rhythms constrain leaf and canopy gas exchange in an Amazonian forest, Geophys. Res. Lett., 33, L15404 doi:15410.11029/12006GL026750, 2006.

Falge, E., Baldocchi, D., Olson, R., Anthoni, P., Aubinet, M., Bernhofer, C., Burba, G., Ceulemans, R., Clement, R., Dolman, H., Granier, A., Gross, P., Grünwald, T., Hollinger, D., Jensen, N.O., Katul, G., Keronen, P., Kowalski, A., Ta Lai, C., Law, B. E., Meyers, T., Moncrieff, J., Moors, E., Munger, J. W., Pilegaard, K., Rannik, Ü., Rebmann, C., Suyker, A., Tenhunen, J., Tu, K., 
Verma, S., Vesala, T., Wilson, K., and Wofsy, S.: Gap filling strategies for defensible annual sums of net ecosystem exchange, Agric. For. Meteorol., 107, 43-69, 2001.

Forster, P., Ramaswamy, V., Artaxo, P., Berntsen, T., Betts, R., Fahey, D. W., Haywood, J., Lean, J., Lowe, D. C., Myhre, G., Nganga, J., Prinn, R., Raga, G., Schulz, M., and Van Dorland, R.: Changes in atmospheric constituents and in radiative forcing, Climate change 2007: The physical science basis, Contribution of working group I to the Fourth Assessment Report of the Intergovernmental Panel on Climate Change. Cambridge University Press, Cambridge, United Kingdom and New York, NY, USA, 2007.

Gil-de-Carrasco, C., Cañadas Hernández, D., and de-Oliveira, P.V.: El dominio periglaciar nevadense en la provincia de Almería y sus repercusiones sobre los suelos, vegetación y rasgos superficiales, Investigación y Gestion, 3, 129-138, 1997.

Goulden, M. L., Munger, J. W., Song-Miao, F., Daube, B. C., and Wofsy, S. C.: Measurements of carbon sequestration by longterm eddy covariance: methods and critical evalution of accuracy, Global Change Biol., 2, 169-182, 1996.

Granier, A., Reichstein, M., Bréda, N., Janssens, I. A., Falge, E., Ciais, P., Grünwald, T., Aubinet, M., Berbigier, P., Bernhofer, C., Buchmann, N., Facini, O., Grassi, G., Heinesch, B., Ilvesniemi, H., Keronen, P., Knohl, A., Köstner, B., Largergren, F., Lindroth, A., Longdoz, B., Loustau, D., Mateus, J., Montagnani, L., Nys, C., Moors, E., Papale, D., Peiffer, M., Pilegaard, K., Pita, G., Pumpanen, J., Rambal, S., Rebmann, C., Rodrigues, A., Seufert, G., Tenhunen, J., Vesala, T., and Wang, Q.: Evidence for soil water control on carbon and water dynamics in European forests during the extremely dry year: 2003, Agric. For. Meteorol., 243, 123-145, 2007.

Grelle, A. and Burba, G. G.: Fine-wire thermometer to correct $\mathrm{CO}_{2}$ fluxes by open-path analyzers for artificial density fluctuations, Agric. For. Meteorol., 147, 48-57, 2007.

Haslwanter, A., Hammerle, A., and Wohlfahrt, G.: Open-path vs. close-path eddy covariance measurements of the net ecosystem carbon dioxide and water vapor exchange: A long-term perspective, Agric. For. Meteorol., 149, 291-302, 2009.

Hölttä, T., Cochard, H., Nikinmaa, E., and Mencuccini, M.: Capacitive effect of cavitation in xylem conduits: results from a dynamic model, Plant, Cell \& Environment, 32, 10-21, 2009.

Hu, J., Moore, D. J. P., Burns, S. P., and Monson, R. K.: Longer growing seasons lead to less carbon sequestration by a subalpine forest, Global Change Biol., 16, 771-783, 2009.

Huxman, T. E., Snyder, K. A., Tissue, D., Leffler, A. J., Ogle, K., Pockman, W. T., Sandquist, D. R., Potts, D. L., and Schwinning, S.: Precipitation pulses and carbon fluxes in semiarid and arid ecosystems, Oecologia, 141, 254-268, 2004.

IPCC: Climate change 2007: The physical science basis, contribution of working group I to the Fourth Assessment Report of the Intergovernmental Panel on Climate Change, edited by: Solomon, S., Qin, D., Manning, M., Chen, Z., Marquis, M., Averyt, K. B., Tignor, M., and Miller, H. L.m Cambridge University Press, Cambridge, United Kingdom and New York, NY, USA, 996 pp, 2007.

Järvi, L., Mammarella, I., Eugster, W., Ibrom, A., Siivola, E., Dellwik, E., Keronen, P., Burba, G., and Vesala, T.: Comparison of net $\mathrm{CO}_{2}$ fluxes measured with open- and closed-path infrared gas analyzers in urban complex environment, Boreal Environ. Res.,
14, 499-514, 2009.

Jones, H. G.: Plants and microclimate: A Quantitative Approach to Environmental Plant Physiology, Cambridge University Press, New York, ISBN: 9780521425247, 1992.

Klute, A.: Methods of soil analysis. Part 1. Physical and mineralogical methods. Book series 5, ASA/SSSA, Madison, WI, USA, 1986.

Kowalski, A. S., Anthoni, P. M., and Vong, R. J.: Deployment and evaluation of a system for ground-based measurements of cloud liquid water turbulent fluxes, Am. Meteorol. Soc., 14, 468-479, 1997.

Lafleur, P. M. and Humphreys, E. R.: Spring warming and carbon dioxide exchange over low Arctic tundra in central Canada, Global Change Biol., 14, 740-756, 2007.

Lambers, H., Chapin, F. S., and Pons, T. L.: Plant Physiological Ecology, Springer-Verlag, 540 pp., 1998.

McMillen, R. T.: An eddy correlation technique with extended applicability to non-simple terrain, Bound. Lay. Meteorol., 43, 231-245, 1988.

Moncrieff, J. B., Malhi, Y., and Leuning, R.: The propagation of errors in long-term measurements of land-atmosphere fluxes of carbon and water, Global change biology, 2, 231-240, 1996.

Monson, R. K., Burns, S. P., Williams, M. W., Delany, A. C., Weintraub, M., and Lipson, D. A.: The contribution of beneathsnow soil respiration to total ecosystem respiration in a highelevation, subalpine forest, Global Biogeochem. Cycles, 20, GB3030, doi:10.1029/2005GB002684, 2006a.

Monson, R. K., Lipson, D. A., Burns, S. P., Turnipseed, A. A., Delany, A. C., Williams, M. W., and Schmidt, S. K.: Winter forest soil respiration controlled by climate and microbial community composition, Nature, 439, 711-714, 2006b.

Musselman, R. C., Massman, W. J., Frank, J. M., and Korfmacher, J. L.: The temporal dinamics of carbon dioxide under snow in a high elevation Rocky Mountain subalpine forest and meadow, Artic, Antartic and Alpine Res., 37, 527-538, 2005.

Oechel, W. C., Hastings, S. J., Vourlitis, G., Jenkins, M., Riechers, G., and Grulke, N.: Recent change of Arctic tundra ecosystems from a net carbon dioxide sink to a source, Nature, 361, 520-523, 1993.

Ono, K., Miyata, A., and Yamada, T.: Apparent downward $\mathrm{CO}_{2}$ flux observed with open-path eddy covariance over a non-vegetated surface, Theor. Appl. Climatol., 92, 195-208, 2008.

Prieto-Fernández, P.: Flora de la tundra de Sierra Nevada, Secretariado de publicaciones de la Universidad de Granada, Un.Gr.47.75.11 Dep.leg.Gr.85.1975, ISBN.84.600.1810.1815., 1975.

Pryor, S. and Barthelmie, R. J.: Nitrogen dry deposition at an AmeriFlux site in a hardwood forest in the MidWest, Geophys. Res. Lett., 26, 691-694, 1999.

Reichstein, M., Falge, E., Baldocchi, D., Papale, D., Aubinet, M., Berbigier, P., Bernhofer, C., Buchmann, N., Gilmanov, T., Granier, A., Grünwald, T., Havránková, K., Ilvesniemi, H., Janous, D., Knohl, A., Laurila, T., Lohila, A., Loustau, D., Matteucci, G., Meyers, T., Miglietta, F., Ourcival, J.-M., Pumpanen, J., Rambal, S., Rotenger, E., Sanz, M., Tenhunen, J., Seufert, G., Vaccari, F., Vesala, T., Yakir, D., and Valentini, R.: On the separation of net ecosystem exchange into assimilation and ecosystem respiration: review and improved algorithm, Global Change Biol., 11, 1424-1439, 2005. 
Resco, V., Hartwell, J., and Hall, A.: Ecological implications of plants' ability to tell the time, Ecology Lett., 12, 583-592, 2009.

Richardson, A. D., Hollinger, D. Y., Burba, G. G., Davis, K. J., Flanagan, L. B., Katul, G. G., Munger, J. W., Ricciuto, D. M., Stoy, P. C., Suyker, A. E., Verma, S. B., and Wofsy, S. C.: A multi-site analysis of random error in tower-based measurements of carbon and energy fluxes, Agric. For. Meteorol., 136, 1-18, 2006.

Richardson, A. D. and Hollinger, D. Y.: A method to estimate the additional uncertainty in gap-filled NEE resulting from long gaps in the $\mathrm{CO}_{2}$ flux record, Agric. For. Meteorol., 147, 199-208, 2007.

Sala, O. E., Lauenroth, W. K., and Parton, W. J.: Plant recovery following prolonged drought in a shortgrass steppe, Agric. Meteorol., 27, 49-58, 1982.

Sánchez, S., Simon, M., García, I., and Gómez Ortiz, A.: Morfogenesis de un sistema nival de Sierra Nevada: Laguna Seca (provincia de Granada), Cuaternario y geomorfología, 2, 99-105, 1988.

Schimel, D., Kittel, T. G. F., Running, S., Monson, R., Turnipseed, A., and Anderson, D.: Carbon sequestration studied in western US mountains, EOS, Transactions, American Geophysical Union, 83, 445-449, 2002.

Skinner, H.: Winter carbon dioxide fluxes in humid-temperate pastures, Agric. For. Meteorol., 144, 32-43, 2007.

Sparks, D. L.: Methods of soil analysis. Part 3. Chemical methods. Book series 5. ASA/SSSA, Madison, WI, USA, 1996.

Spehn, E. M. and Körner, C.: A global assessment of mountain biodiversity and its function, Global Change and Mountain Regions, 1, 393-400, 2005.

Sperry, J. S., Meinzer, F. C., and McCulloh, K. A.: Safety and efficiency conflicts in hydraulic architecture: scaling from tissues to trees, Plant, Cell \& Environment, 31, 632-645, 2008.

Starr, G. and Oberbauer, S. F.: Photosynthesis of artic evergreen under snow: implications for tundra ecosystem carbon balance, Ecology, 84, 1415-1420, 2003.
Tyree, M. T. and Sperry, J. S.: Do woody plants operate near the point of catastrophic xylem dysfunction caused by dynamic water stress? Answers from a model, Plant Physiol., 88, 574-580, 1988.

Webb, A. A. R.: The physiology of circadian rhythms in plants, New Phytologist, 160, 281-303, 2003.

Webb, E. K., Pearman, G. I., and Leuning, R.: Correction of flux measurements for density effects due to heat and water vapour transfer, Q. J. Roy. Meteorol. Soc., 106, 85-100, 1980.

Wohlfahrt, G., Anfang, C., Bahn, M., Haslwanter, A., Newesely, C., Shmitt, M., Drösler, M., Pfadenhauer, J., and Cernusca, A.: Quantifying nighttime ecosystem respiration of a meadow using eddy covariance, chambers and modelling, Agric. For. Meteorol., 128, 141-162, 2005.

Wohlfahrt, G., Anderson-Dunn, M., Bahn, M., Balzarolo, M., Berninger, F., Campbell, C., Carrara, A., Cescatti, A., Christensen, T., Dore, S., Eugster, W., Friborg, T., Furger, M., Gianelle, D., Gimeno, C., Hargreaves, K., Hari, P., Haslwanter, A., Johansson, T., Marcolla, B., Milford, C., Nagy, Z., Nemitz, E., Rogniers, N., Sanz, M. J., Siegwolf, R. T. W., Susiluto, S., Sutton, M., Tuba, Z., Ugolini, F., Valentini, R., Zorer, R., and Cernusca, A.: Biotic, abiotic, and management controls on the net ecosystem $\mathrm{CO}_{2}$ exchange of European mountain grassland ecosystems, Ecosystems, 11, 1338-1351, 2008a.

Wohlfahrt, G., Fenstermaker, L. F., and Arnone, J. A.: Large annual net ecosystem $\mathrm{CO}_{2}$ uptake of a Mojave Desert ecosystem, Global Change Biol., 14, 1475-1487, 2008b.

Yu, G. R., Wen, X. F., Sun, X. M., Tarner, B. D., Lee, X., and Chen, J. Y.: Overview of ChinaFLUX and evaluation of its eddy covariance measurements, Agric. For. Meteorol., 137, 125-137, 2006. 